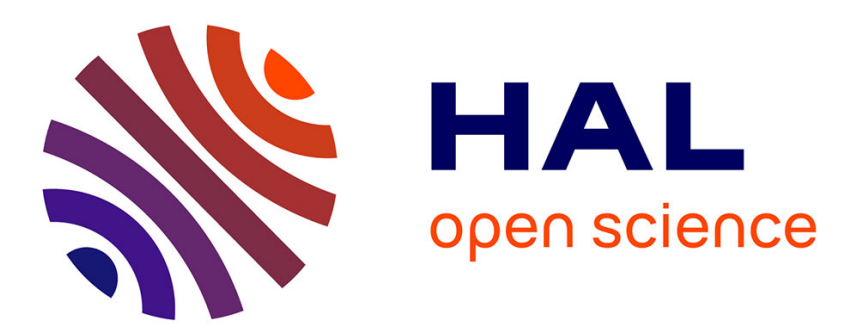

\title{
Quantifying peakflow attenuation/amplification in a karst river using the diffusive wave model with lateral flow
}

\author{
Jean-Baptiste Charlier, Roger Moussa, Pierre-Yann David, Jean-François
} Desprats

\section{To cite this version:}

Jean-Baptiste Charlier, Roger Moussa, Pierre-Yann David, Jean-François Desprats. Quantifying peakflow attenuation/amplification in a karst river using the diffusive wave model with lateral flow. Hydrological Processes, 2019, 33 (17), pp.2337-2354. 10.1002/hyp.13472 . hal-02273711

\section{HAL Id: hal-02273711 https://hal-brgm.archives-ouvertes.fr/hal-02273711}

Submitted on 29 Aug 2019

HAL is a multi-disciplinary open access archive for the deposit and dissemination of scientific research documents, whether they are published or not. The documents may come from teaching and research institutions in France or abroad, or from public or private research centers.
L'archive ouverte pluridisciplinaire HAL, est destinée au dépôt et à la diffusion de documents scientifiques de niveau recherche, publiés ou non, émanant des établissements d'enseignement et de recherche français ou étrangers, des laboratoires publics ou privés. 


\section{Quantifying peakflow attenuation/amplification in a karst river using}

2 the diffusive wave model with lateral flow

3

4

5 Jean-Baptiste Charlier ${ }^{*}, 1$, Roger Moussa ${ }^{2}$, Pierre-Yann David ${ }^{3}$, Jean-François Desprats ${ }^{1}$

6

$7 \quad{ }^{1}$ BRGM, Univ. Montpellier, Montpellier, France.

$8{ }^{2}$ LISAH, Univ. Montpellier, INRA, IRD, Montpellier SupAgro, Montpellier, France

$9 \quad{ }^{3}$ BRGM, F-76130 Mont Saint-Aignan, France.

$10 *$ corresponding author: e-mail: j.charlier@brgm.fr; Tel: +33 (0)4 67157977

11

12

13

14

15

16

Key words

17 Flood; Lateral flow; Karst, Diffusive wave model; Peakflow attenuation or amplification;

Surface water / groundwater interactions

19 


\section{Abstract}

22 The aim of this paper is to quantify peakflow attenuation and/or amplification in a river, 23 investigating lateral flow from the intermediate catchment during floods. This is a challenge 24 for the study of the hydrological response of permeable/intermittent streams, and our contribution refers to a modelling framework based on the inverse problem for the diffusive wave model applied in a karst catchment. Knowing the upstream and downstream hydrographs on a reach between two stations, we can model the lateral one, given information on the hydrological processes involved in the intermediate catchment. The model is applied to 33 flood events in the karst reach of the Iton River in French Normandy where peakflow attenuation is observed. The monitored zone consists of a succession of losing and gaining reaches controlled by strong surface-water / groundwater (SW/GW) interactions. Our results show that, despite a high baseflow increase in the reach, peakflow is attenuated. Model application shows that the intensity of lateral outflow for the flood component is linked to upstream discharge. A combination of river loss and overbank flow for highest floods is proposed for explaining the relationships. Our approach differentiates the role of outflow (river loss and overbank flow) and that of wave diffusion on peakflow attenuation. Based on several sets of model parameterization, diffusion is the main attenuation process for most cases, despite high river losses of up to several $\mathrm{m}^{3} / \mathrm{s}$ (half of peakflow for some parameterization strategies). Finally, this framework gives new insight into the SW/GW interactions during floods in karst basins, and more globally in basins characterized by disconnected river-aquifer systems. 


\section{Introduction}

In a catchment densely monitored for hydrological surveying, flood-flow generation can be investigated at the network scale in reaches between two gauging stations. In such a runoffrunoff approach, flows from the intermediate catchment can be significant contributors of flood flow at the outlet, depending on catchment geometry and hydrological conditions. Although lateral flow from the intermediate catchment is well documented for low-water periods, investigating for instance surface-water / groundwater (SW/GW) interactions in successive reaches (Covino et al., 2011; Mallard et al., 2014), there is a lack of information on how to define lateral flow during flood events.

As shown on Figure 1, several types of lateral flow occur during floods, depending upon catchment descriptors such as climate, relief, geology, soil, etc. For highest peakflows, lateral outflow (Figure 1a) is generally considered in the case of overbank flow when waters from the river flow to the flood plain, without been returned to the river during the flood (Jothityangkoon \& Sivapalan, 2003; Moussa and Bocquillon, 2009), modifying the shape of the hydrograph (Rak et al., 2016; Fleischmann et al., 2018). Another case favouring lateral outflow is specific to permeable basins, where river losses infiltrate and recharge the underlying aquifer (Sorman et al., 1997; Charlier et al., 2015b; Dvory et al., 2018). This is notably the case in arid/Mediterranean environment, where the importance of infiltrating floodwater for aquifer recharge has been highlighted in disconnected river- aquifer systems (Hughes \& Sami, 1992; Camarasa Belmonte \& Segura Beltrán, 2001; Lange, 2005; Dahan et al., 2007; Vázquez- Suñé et al., 2007). Lateral inflow (Figure 1b) is often taken into account in flood modelling due to its common occurrence in all types of catchments (e.g., Cimorelli et al., 2014;2018). Most inflow comes from tributaries (point lateral flow) or from hillslope runoff (distributed lateral flow). In permeable basins, groundwater flooding can also cause large lateral inflows (Finch et al., 2004; Pinault et al. 2005; Naughton et al., 2012), but this 
simple typology can mask a greater complexity of lateral flows. In most cases, several processes are spatially and temporally combined, leading to mixed (and maybe compensated) out- and in-flows during flooding, as shown on Figure 1c.

Investigating flood generation in a carbonate catchment is of great interest because it is highly controlled by SW/GW interactions. Following Robins and Finch (2012), a true groundwater flood - where the groundwater level rises above ground surface-is distinguished from a groundwater-induced flood-which occurs as an intense groundwater discharge through springs and permeable shallow horizons into surface waters. These types of flooding notably occur in chalk terrains of Northern Europe (Finch et al., 2004; Pinault et al., 2005; Hughes et al., 2011; Morris et al., 2015; Thiéry et al. 2018), where extreme events were caused by exceptionally high groundwater levels in 2000-2001. Flood generation in these cases was driven by saturation of the matrix porosity (Price et al., 2000), and is associated to longduration floods due to the aquifer inertia.

When carbonate formations are highly karstified, which can be the case in chalk formations, groundwaters contribute to the fast-flow component in streams (Maréchal et al., 2008; Charlier et al., 2015b), playing a significant role in flooding, even for flash floods. In karst basins, flooding may also occur by the cessation of rainfall infiltration because of the small retention capacity of a karst massif (Maréchal et al. 2008; Fleury et al. 2013), or because the infiltration capacity of the underground conduit network is exceeded (Lopez-Chicano et al. 2002; Bonacci et al. 2006; Bailly-Comte et al. 2009). As chalk aquifers are often karstified, specific types of groundwater flooding can occur seasonally, as is reported from Ireland in low-lying topographic depressions, known as turloughs, that are fed by underground flow from karst aquifers (Naughton et al., 2012; Gill et al., 2013).

Another frequent feature of flood generation in karst basins is a contrasted evolution of peakflow, i.e. amplification or attenuation, in a same reach depending upon the prior aquifer 
saturation level (Maréchal et al., 2008; Charlier et al., 2015b). In catchments characterized by a high storage potential in thick unsaturated zones of karst aquifers, peakflow attenuation is common (Jourde et al., 2013; Ladouche et al., 2014; Brunet \& Bouvier, 2017), which may add to the attenuation due to flood-wave diffusion in the channel. Attenuation is also enhanced in medium and large catchments, where diffusion is favoured due to the development of drainage networks in lowland areas (e.g., Moussa \& Cheviron, 2015; Trigg et al., 2009) and due to the occurrence of overbank flow (see a synthesis in Bates \& De Roo, 2000; Hunter et al., 2007; Moussa \& Bocquillon, 2009). In karst massifs, the drainage is often developed in canyons that cross-cut the carbonate plateau, where the channel commonly is rougher. We can suppose that this will favour a velocity decrease of the flood wave due its meandering feature. Finally, there is a need in such a context to understand the respective roles of lateral outflow (losses, overbank flow) and flood routing in peakflow attenuation.

Many modelling methods exist for investigating SW/GW interactions on groundwater flooding. As the hydrogeological context of chalk aquifers can be favourable for applying physically-based models, lumped approaches (Pinault et al., 2005; Upton \& Jackson, 2011) were completed by distributed models, such as MODCOU (Korkmaz et al., 2009), SIM (Habets et al., 2010), MIKE SHE (House et al., 2016), or MARTHE (Thiéry et al., 2018). However, the specifics of karst basins with their high degree of complexity prevent an efficient application of such distributed models, and few such modelling approaches have been used for characterizing SW/GW interactions during flood events in karst basins. To our knowledge, the only published work on the application of flood-routing models to channel reaches, is based on the simplified Saint-Venant equation that describes unsteady flow in partially filled channels; a first modelling approach for karst areas was proposed by BaillyComte et al. (2012), using the Kinematic Wave Equation coupled with a linear underground reservoir for simulating lateral inflow. Recently, Charlier et al. (2015b) tested the relevance of 
118 the Diffusive Wave Equation (DWE) for assessing lateral in- and outflows in karst rivers.

119 DWE is more adapted to floods with large wavelengths, common in medium and large 120 catchments (Ponce, 1990). Moreover, Moussa (1996) extended the analytical solution of the

121 DWE under the Hayami (1951) hypothesis (Moussa \& Bocquillon, 1996b) to the case of

122 uniformly distributed lateral flow. The model can calculate the temporal distribution of lateral

123 flow in a river reach by an inverse problem approach, using as input the flow in both the

124 upstream and downstream gauging stations. The solution of the inverse problem proposed is 125 part of the hydrological MHYDAS model (Distributed Hydrological Modelling of

126 AgroSystems ; Moussa et al., 2002). Using this inverse problem for the DWE we can simulate

127 the global dynamics of lateral flow during floods, which provides information on the

128 hydrological processes involved, such as tracking loss and gain reaches in rivers (Charlier et

129 al., 2015b), or characterizing matrix/conduit relationships through the underground network

130 of a karst aquifer (Cholet et al., 2017); both these publications showed promises in the ability

131 of such models to quantify lateral flow in a karst basin.

132 The aim of this paper is therefore to quantify peakflow attenuation/amplification in a river,

133 and to investigate lateral flow during floods. For that, we propose a modelling framework to

134 simulate lateral flow from an intermediate catchment, using the inverse problem for the DWE.

135 The model is applied to 33 flood events in the karst reach of the Iton River in French

136 Normandy, where peakflow is attenuated. After analysing the role of groundwater on flood

137 generation, the model is used for quantifying the peakflow attenuation. The respective roles of

138 outflow and wave diffusion on peakflow attenuation are described according to various

139 parameterization strategies. Investigating the sensitivity of model parameterization, we

140 provide a new way for better understanding and quantifying flood routing through accounting

141 for lateral flow. 


\section{Modelling approach}

\section{3 \\ 2.1 The diffusive wave model}

144 In order to model 1-D unsteady flow in open channels, the Saint-Venant equations can be

145 simplified under some assumptions (acceleration terms neglected), leading to the Diffusive 146 Wave Equation (DWE) (Moussa \& Bocquillon, 1996a), which corresponds to the case of long 147 wave-length flood events generally observed in medium and large basins:

148 Eq. 1

$$
\frac{\partial Q}{\partial t}+C \frac{\partial Q}{\partial x}-D \frac{\partial^{2} Q}{\partial x^{2}}=0
$$

149 where $x[\mathrm{~L}]$ is the length along the channel, $t[\mathrm{~T}])$ is the time, and the celerity $C\left[\mathrm{~L} \cdot \mathrm{T}^{-1}\right]$ and

150 the diffusivity $D\left[\mathrm{~L}^{2} \mathrm{~T}^{-1}\right]$ are functions of the discharge $Q\left[\mathrm{~L}^{3} \mathrm{~T}^{-1}\right]$. In this case, we have a 151 simple two-parameters $(C, D)$ model.

152 At the scale of a river reach - delimited by an input $I$ and an output $O$ station - the model is

153 applied to the flood component $\left(Q_{I f}(t)\right.$ and $\left.Q_{O} f(t)\right)$ of the total discharge $\left(Q_{I}(t)\right.$ and $\left.Q_{O}(t)\right)$

154 recorded at the input and output stations, respectively. $Q_{I f}(t)$ and $Q_{O f}(t)$ are estimated by 155 removing the baseflow components $Q_{I b}(t)$ and $Q_{O b}(t)$ from $Q_{I}(t)$ and $Q_{O}(t)$.

156 The resolution of Eq. 1 is obtained using the convolution approach proposed by Moussa 157 (1996) based on the Hayami assumptions (Hayami, 1951), i.e. considering $C$ and $D$ as 158 constant parameters over time along a channel of length $l$ :

Eq. 2: $\quad Q_{I f r}(t)=\int_{0}^{p} Q_{I f}(t-\tau) K(\tau) \mathrm{d} \tau=Q_{I f}(t) * K(t)$

160 Where $Q_{I f r}(t)$ is the routed input hydrograph on the flood component, $p$ is the time memory of

161 the system, and the symbol * represents the convolution operator. As there is no problem of

162 calculation time, the term $p$ must be large in comparison to the travel time along a channel 163 reach. In Eq. 2, the Hayami kernel function $K(t)$ is expressed as follows: 
$164 \quad$ Eq. $3 \quad K(t)=\frac{l}{2(\pi D)^{1 / 2}} \frac{\exp \left[\frac{C l}{4 D}\left(2-\frac{l}{C t}-\frac{C t}{l}\right)\right]}{t^{3 / 2}}$

165 Eq. 2 is then used in a direct approach to define the $C$ and $D$ parameters, comparing $Q_{I f r}(t)$

166 with $Q_{o f}(t)$. In a theoretical case without lateral flows, under diffusive wave and Hayami

167 asumptions, the routed input hydrograph is equal to the observed output one $\left(Q_{I f r}(t)=Q_{O f}(t)\right)$

168 as shown on Figure 2a.

\subsection{The diffusive wave model with lateral flows}

170 Several solutions exist to resolve the DWE with lateral flows (see Cimorelli et al. (2014) for a

171 review). In our paper, the one proposed by Moussa (1996) has been selected because an

172 analytical solution has been proposed to solve the inverse problem, as explained herein.

173 Moreover recently, an experimental evaluation of the solution has been performed by Moussa 174 and Majdalani (2019) on a large variety of hydrograph scenarios. The model is based on

175 Hayami assumptions, considering i) diffuse lateral flows as uniformly distributed along the

176 channel reach, and ii) the two $C$ and $D$ parameters as constant over time during the flood. It is

177 used to route the input hydrograph to the output station accounting for lateral flows. A

178 solution to the inverse problem of the DWE is used to model lateral flows, knowing the input

179 and the output hydrographs. This last case is suitable to be used when no observations on

180 lateral flows are available. Indeed, it gives information on the potential contributions of the

181 intermediate catchment, and notably on the estimation of peakflow of the lateral hydrograph.

182 Implementing lateral flows in the DWE needs to account for the lateral flow rate $q$ per unit

183 length $\left[\mathrm{L}^{2} \mathrm{~T}^{-1}\right]$ along a channel reach, as proposed by Moussa (1996):

184 Eq. $4 \quad \frac{\partial Q}{\partial t}+C\left(\frac{\partial Q}{\partial x}-q\right)-D\left(\frac{\partial^{2} Q}{\partial x^{2}}-\frac{\partial q}{\partial x}\right)=0$

185 In the particular case of uniform distribution of $q$ along the reach, under the hypotheses used

186 in the Hayami model ( $C$ and $D$ constant), Moussa (1996) proposes an analytical resolution: 


$$
Q_{I f r}(t)=\Phi(t)+\left(Q_{I f}(t)-\Phi(t)\right) * K(t)
$$

188

Eq. 6 with $\Phi(t)=\frac{C}{l} \int_{0}^{t}\left[Q_{A f}(\lambda)-Q_{A f}(0)\right] d \lambda$

$$
\text { Eq. } 7 \text { and with } Q_{A f}(t)=\int_{0}^{l} q(x, t) . \mathrm{dx}
$$

190 where $q(x, t)\left[\mathrm{L}^{2} \mathrm{~T}^{-1}\right]$ is the lateral flow rate per unit length as a function of distance along the

191 channel reach $x . Q_{A} f(t)$ represents the flood component of the lateral hydrograph $Q_{A}(t)$. As

192 illustrated on Figure 2b,c, the expression $q(x, t)$ may be positive or negative depending upon

193 the lateral flow direction from the channel when inflow or outflow occurred, respectively.

194 According to Moussa (1996), the inverse problem identifies $Q_{A} f(t)$ by knowing $Q_{I f}(t)$ and $Q_{O}$

$195 f(t)$, and according to a predetermination of the two parameters $C$ and $D$. Given that,

196 Eq. $8 \quad Q_{A f r}(t)=Q_{O f}(t)-Q_{I f r}(t)$

197

Eq. $9 \quad$ with $\quad \Phi(t)-\Phi(t) * K(t)=Q_{A f r}(t)$

198 Using the Laplace transforms, an approximation of the solution of Eq. 9 is

199

Eq. 10

$$
\Phi(t)=Q_{A f r}(t)+Q_{A f r}(t) \sum_{i=1}^{\infty} K^{i}(t)
$$

200 with

201

Eq. 11

$$
K^{i}(t)=K * K * \ldots * K \quad(i \text { times })
$$

$202 Q_{A f}(t)$ can be easily calculated using Eq. 12, after the identification of $K(t)$ in Eq. 3:

203 Eq. 12

$$
Q_{A f}(t)=\frac{l}{C} \frac{d \Phi}{\mathrm{dt}}
$$

204 The lateral hydrograph $Q_{A}(t)$ is simply calculated from $Q_{A f}(t)$ by adding $Q_{A}(t)$, the difference 205 of baseflow $\left(Q_{O b}(t)-Q_{I b}(t)\right)$ between $O$ and $I$ stations. 
When no observations of $Q_{A}(t)$ are available to calibrate the model, this simple approach with two parameters $(C, D)$ is favoured. This choice is made in comparison with more complex approaches adding a further degree of freedom, by considering additional parameters. Thus, according to the principle of parsimony, we choose the most simplest and robust model, considered as more reasonable. For the inverse problem, many couples of solutions $(C, D)$ exist to simulate $Q_{A}(t)$. In our paper, the sensitivity on the various couples of solutions $(C, D)$

212 is then characterized to assess whether the different solutions brings some different interpretations or not on the lateral contributions.

\subsection{Quantification of the peakflow amplification/attenuation}

215 Based on the conceptual schemes of Figure 1, we expect that the global lateral flow at a given 216 time is the sum of simultaneous negative and positive $q$ values originating from various 217 processes. Knowing this, we now must understand the causes of the attenuation or 218 amplification of peakflow (without the baseflow component) shown on Figure 2, from the 219 upstream station $Q x_{I f}$ [peakflow of the input hydrograph $Q_{I f}(t)$ : black curve] to the 220 downstream one $Q x_{O f}$ [peakflow of the output hydrograph $Q_{O f}(t)$ : blue curve]. The difference 221 between both peakflows is noted $E$ :

$$
E=Q x_{O f}-Q x_{I f}=E_{D}+E_{A}
$$

with $E>0$ in the case of peakflow amplification (Figure $2 \mathrm{~b}$ ), and with $E<0$ in the case of attenuation (Figure 2c ). $E$ is composed of two terms linked to the hydraulic properties of the channel $E_{D}$ (controlled by $D$ parameter), and linked to the lateral flows $\left(E_{A}\right)$. Noted that in the case of no-lateral flow component (Figure 2a), $E_{A}=0$ and $E=E_{D} \leq 0$.

227 Diffusion is responsible for a peakflow attenuation $E_{D}$ of the input hydrograph expressed as 228 follows:

$$
E_{D}=Q x_{I f r}-Q x_{I f} \quad \text { with } E_{D} \leq 0
$$


with $Q x_{I f r}$, the peakflow of the routed input hydrograph $Q_{I f r}(t)$ without lateral flow (dashed

231 grey curve). Lateral flow is responsible for an attenuation/amplification expressed as:

232 Eq. 15

$$
E_{A}=Q x_{O f}-Q x_{I f r}
$$

233 Depending upon the importance of out- and in-flows, $E_{A}$ may be negative or positive, 234 respectively.

235 Hereafter, we investigate the flood processes in a catchment favouring peakflow attenuation $236(E<0)$ according to high diffusion $\left(E_{D}<0\right)$ and the occurrence of river losses and overbank 237 flow $\left(E_{A}<0\right)$.

\subsection{Sensitivity analysis on a virtual example}

239 To illustrate the model behaviour and its calibration, various parameterization sets of $C$ and $D$ 240 parameters were used to apply the inverse model on the same couple of theoretical 241 hydrographs $Q_{I f}$ and $Q_{o f}$ (Figure 3). Figure 3a and 3b present the simulations carried out by

242 fixing $D$ and varying $C$. In the case of a gaining reach (Figure 3a), the results show that the 243 highest lateral peakflow is simulated for the lower $C$. When increasing $C$, lateral peakflow 244 decreased and became constant when $C$ exceeded a threshold (here $C>0.4 \mathrm{~m} / \mathrm{s}$ ) at the same 245 time that outflow was simulated at the start of the flood event. This illustrates a dynamics of 246 compensation of out- and inflows during the same flood event due to a conservation of the 247 flood volume (total lateral flood volume was equal for all simulation tests). The model 248 behaviour is simpler in the case of a losing reach, because Figure $3 \mathrm{~b}$ shows that the higher the $249 C$, the higher and the earlier will be the lateral outflow peak. Figure $3 \mathrm{c}$ and $3 \mathrm{~d}$ show a similar 250 test, but now fixing $C$ and varying $D$. In the case of lateral inflow (Figure 3c), the results 251 showed that the higher the $D$, the higher will be lateral peakflow. Similar to Figure 3a, 252 temporal lateral outflow is simulated at the beginning of the flood when $D$ increases. In the 253 case of a losing reach (Figure $3 \mathrm{~d}$ ), the higher the $D$, the higher and the earlier will be the 
254 lateral outflow peak. Globally, this sensitivity analysis shows that various lateral hydrographs

255 are simulated for different couples of $C$ and $D$ parameters, due to equifinality in the modelling 256 approach. As observed in previous studies (Moussa \& Bocquillon, 1996a; Yu et al., 2000;

257 Charlier et al., 2009; Cholet et al., 2017), $C$ is more sensitive than $D$, as a variation of $C$ by 4 258 in our test case generated a same range of lateral peakflow variations as a variation of $D$ by $25910,000$.

260 Consequently, for a given flood event, the $C$ and $D$ parameters should be optimized. In our 261 case, we expect that, whatever the flood, the fast component of lateral flow will contribute to 262 peakflow at the output station. Thus, we chose to optimize $C$ and $D$ in order to put in phase 263 peakflows of the routed inflow and outflow hydrographs. Figure $3 \mathrm{e}$ and $3 \mathrm{f}$ show the effect of 264 the inverse model, varying $D$ and calibrating $C$ under these conditions. Regarding the 265 evolution of parameters, it shows that $C$ decreases when $D$ increases, but up to a lower limit (of $C=0.22 \mathrm{~m} / \mathrm{s}$ in our case for $D>150 \mathrm{~m}^{2} / \mathrm{s}$ ). In the case of a gaining reach (Figure 3e), the higher the $D$, the higher will be the lateral peakflow, but for a losing reach (Figure $3 \mathrm{f}$ ), the

268 higher is the $D$, the lower will be lateral outflow peakflow. These results show that, contrary 269 to varying $D$ and fixing $C$ (Figure 3 b), lateral outflow peakflow decreases when $D$ increases, provided the corresponding $C$ is optimized following the hypothesis of a same routing scheme 271 for lateral out- and in-flows.

\section{$272 \quad 2.5 \quad$ Framework of the modelling approach used}

273 We propose a framework in this paper for defining amplification/attenuation of peakflows in a 274 river reach. Though interpretation of the results will obviously be better when confronting 275 them with field knowledge, the model application can stand alone in order to help decipher 276 some hydrological processes in catchments with a complex behaviour. The modelling 277 framework has four steps: 
- First, the base and flood components of the hydrographs at the two gauging stations must be separated;

- Second, calibration of the DW model parameters ( $C$ and $D)$ applying the direct approach without lateral flow (Eq. 2). We saw above how the calibration strategy may influence the results, and we thus must optimize $C$ and $D$ by inputting phase peakflow of the routed inflow $Q x_{I f r}$ and of the outflow $Q_{O f}$ (as illustrated on Figure 1);

- Third, is the calculation of the lateral hydrograph, applying the inverse approach of the DW model using in Eq. 10 the pre-calibrated $C$ and $D$ values from Eq. 2;

The choice of the modelling calibration on peakflows proposed in the second step appears to be the most likely in the absence of monitoring lateral flow along the reach. In order to account for the uncertainty on this choice, different sets of simulation by varying $D$ values (and corresponding calibrated $C$ values; see Figure $3 \mathrm{f}$ ) should be carried out. This is tested in 291 the following case study.

\section{Case study}

\section{$293 \quad 3.1 \quad$ Field site}

\section{$294 \quad 3.1 .1 \quad$ Basin presentation}

295 The Iton basin is located in Normandy, north-west France (Figure 4a). Land use consists 296 mainly in cereal crops and grassland, and the only important urban area is Evreux (100,000 297 inhabitants) on the Iton in the downstream part of the basin. The topographic catchment is $2981050 \mathrm{~km}^{2}$ at the Normanville gauging station, $7 \mathrm{~km}$ downstream Evreux city (Figure 4b).

\section{$299 \quad 3.1 .2 \quad$ Climate}

300 The climate is of the humid temperate oceanic type. Annual rainfall ranges between 500 and $3011000 \mathrm{~mm}$, with an inter-annual average of 600 to $715 \mathrm{~mm}$ between the upstream and 302 downstream areas of the catchment, respectively. The intra-monthly variations are relatively 
low, with slightly wetter months in autumn $(60$ to $80 \mathrm{~mm} / \mathrm{mo})$ compared to other periods of

304 the year (40 to $65 \mathrm{~mm} / \mathrm{mo}$ ), but in general rainfall is quite regularly distributed throughout the year. The region has also been characterized in the past by exceptional rainfall in 2000-2001 (about $100 \mathrm{~mm}$ of rainfall depth in 2 to 4 days only), generating catastrophic flood events enhanced probably by two previous years of accumulated wetness (Pinault et al., 2005).

\subsubsection{Geology and hydrogeology}

309 The geomorphological context of the basin can be described as a plateau cross-cut by the Iton

310 River and its main tributary, the Rouloir (Figure 4b). On the plateaux, Late Cretaceous chalk

311 formations are covered by a clayey formation associated with loess, up to several tens of 312 metres thick. In the valley bottom, chalk formations may also be covered by alluvium. Thus, 313 aquifers in the basin are located in the karstified chalk that is mostly covered by shallow 314 formations, as indicated by the non-exposed karst-aquifer symbol in the extract of the World 315 Karst Aquifer map (Chen et al., 2017) in Figure 4a.

316 The underground karst networks in the chalk are fed by diffuse infiltration waters through 317 swallow-holes developed in the (non-cohesive) shallow formations on the plateau, but also 318 from river losses where the chalk is exposed in the river bed. This can generate a drying up of 319 the stream, as in the "Dry-Iton" reach and the Rouloir tributary (Figure 4b). Outlets of these 320 karst aquifers are the springs at the foot of the hillslopes close to the river, and feeding it. The 321 use of artificial tracers (yellow arrows; Figure 4b) showed that infiltrated Iton waters bypass 322 the streambed underground, to reappear downstream in the same bed via resurgence springs 323 located near the confluence with the Rouloir (David et al, 2016).

\section{$324 \quad 3.1 .4$ Conceptual model of lateral flow}

325 The conceptual model presented in Figure $4 \mathrm{c}$ is the result of hydrogeological and hydrological 326 studies, highlighting surface-water / groundwater (SW/GW) interactions of various origin 327 (Charlier et al, 2015a; David et al., 2016). The main horizontal line represents the Iton River 
for the $75-\mathrm{km}$ reach between the two gauging stations Bourth and Normanville (input and

329 output in Figure 4c; see Figure 4b for location). Surface flow is in light blue colour and

330 groundwater flow in dark blue. The dashed line represents ephemeral streams due to river

331 losses. For surface flow, the main properties of the Iton are: i) Drying-up of the drainage

332 network (as well as the Rouloir) where it crosses the karst zone; and ii) Contribution of the

333 main tributary (Rouloir) and of the two groups of springs near the confluence. Groundwater

334 flow is composed of infiltrated river losses as well as aquifer contributions via several springs.

335 Finally, in this conceptual scheme of SW/GW interactions in the Iton basin in its karst part,

336 lateral flow is defined by outflow from river losses and inflow from groundwater origin.

\section{$337 \quad 3.2 \quad$ Data}

\section{$338 \quad$ 3.2.1 Hydrological and hydrogeological time series}

339 Mean rainfall and soil-humidity indices (HU2) over the Bourth and Normanville sub-basins 340 were obtained from METEO FRANCE, available on the COMEPHORE/ANTILOPE and 341 SAFRAN ISBA MODCOU (Habets et al., 2008) databases, respectively. Even if HU2 is not 342 derived from observation data sets, this index is widely used by modelers to initialize 343 hydrological models. Thus, despite the uncertainty on the model output, this is a pertinent data 344 set of soil wetness, that is used as it by end-users (forecasters). Streamflow hydrographs were 345 obtained from the "Service de Prévision des Crues" (SPC) for the Bourth (code: H9402030) 346 and Normanville (code: H9402040) stations, available on Banque Hydro (2015). Groundwater 347 levels were obtained from ADES (2015). All hydrological and hydrogeological time series 348 were synchronized at an hourly time step over the 1999-2014 period.

\section{$349 \quad$ 3.2.2 Flood selection and processing for model application}

350 For flood event analysis, the highest 33 peakflows at the Bourth gauging station (Input 351 station) were selected from the dataset (Table 1). Rainfall events ranged between 16 and $352100 \mathrm{~mm}$, and peakflows between 9 and $26 \mathrm{~m}^{3} / \mathrm{s}$ at the Input station and 5 to $17 \mathrm{~m}^{3} / \mathrm{s}$ at the 
353 Output one. Minimum discharge-inducing overbank flow is 14 and $10 \mathrm{~m}^{3} / \mathrm{s}$ for the Bourth and

354 Normanville stations, respectively. These thresholds correspond to discharge generating flows 355 in the flood plain without rapid return towards the channel. Table 1 shows that the 10 highest 356 flood events were partially subject to overbank flow.

357 The inverse approach of the DW model was applied to the karst portion of the Iton River from 358 hydrographs of the Input (Bourth) and Output (Normanville) stations. Model application 359 requires in a first step a separation of the base and flood components (Section 2.5), which was 360 done with the BFI method (Gustard et al., 1992) using ESPERE software (Lanini et al., 2016).

\section{Results}

$362 \quad 4.1$ Groundwater influence on surface flow

$363 \quad$ 4.1.1 Base and flood components

364 An example of the base and flood flow separation is given in Figure 5 for the 2000-2001 365 hydrological cycle at the Bourth Input station in black (Figure 5a) and the Normanville 366 Output station in blue (Figure 5b). The input-output relationships for the base and flood 367 components account for a 2-day delay (Figure 5c), corresponding to the mean delay of 368 peakflows. It shows a contrasted behaviour: the baseflow increases 3 to 4 fold from input to 369 output station, whereas flood flow decreases by several $\mathrm{m}^{3} / \mathrm{s}$ for the highest flood events. This 370 means that lateral groundwater inflow contributed highly to stream flow for the base 371 component, at the same time that strong lateral outflow occurred for the flood component.

\section{$372 \quad$ 4.1.2 $\quad$ Baseflow analysis}

373 Figure 6 shows the relationships between baseflow calculated at the output gauging station 374 and groundwater levels for six piezometer wells. We observe a slight to fair correlation for 375 wells located on the plateau, having mainly multi-year cycles (Normanville and Cierrey 376 piezometers Figure $4 \mathrm{~b}$ for location). Best correlations are obtained for wells with annual 377 cycles at Nogent-le-Sec, Moisville, and Coulonges (best linear correlation with $\mathrm{R}^{2}>0.7$ ). The 
378 Graveron well, with both multi-year and annual cycles, reflects an intermediate behaviour.

379 These results show that SW/GW interactions on the baseflow component is driven by lateral

380 exchanges with the karst aquifer, best shown by the Coulonges piezometer well.

\section{$381 \quad 4.1 .3 \quad$ Flood analysis}

382 The input-output relationships for peakflow are plotted in Figure 7 according to two factors 383 used as key indices of the catchment saturation level: the soil-humidity index (HU2, Figure 384 7a) and the karst saturation index (GW depth $z$ in the Coulonges well; Figure 7b). Before 385 assessing the effect of such factors, it is interesting to observe that output peakflow is always 386 less than, or equal to, the input one. A peakflow attenuation is also observed for the highest 387 flood events when $\mathrm{Qx}_{\mathrm{I}}>15 \mathrm{~m}^{3} / \mathrm{s}$. This value corresponds to the threshold of overbank flow at 388 the input station, meaning that this process may explain part of the attenuation of the highest 389 flood events. In the first case, HU2 seems not to be a discriminant factor for explaining the 390 data variability, as most events are characterized by indices close to the saturation level (i.e. 391 HU2 60, HU2 ranging between 40 and 65). In the second case, the initial GW depth seems 392 to explain the attenuation variation for a given input peakflow: the higher the initial GW 393 depth, the higher will be output peakflow. Globally, this analysis shows that the soil saturation 394 index is not a suitable factor for differentiating flood intensity. On the contrary, these results 395 show that the peakflow attenuation is related to the antecedent groundwater level.

\section{$396 \quad 4.2$ Simulation of a lateral flood hydrograph}

\section{$397 \quad$ 4.2.1 Model application to a mono-peak flood event}

398 Figure 8 shows an example of the DW model application for the mono-peak flood event of $39906 / 01 / 2001$ with the optimized parameters $C=0.35 \mathrm{~m} / \mathrm{s}$ and $D=500 \mathrm{~m}^{2} / \mathrm{s}$. From top to 400 bottom rainfall, soil saturation index (HU2), groundwater depth in the Coulonges well, 401 discharge for the flood component, and total discharge are shown. On each discharge plot, 402 four hydrographs correspond to the observed input hydrograph ( $Q_{I f}$ and $Q_{I}$; black curve), the 
observed output hydrograph ( $Q_{O f}$ and $Q_{o}$; blue curve), the routed input hydrograph $\left(Q_{I f r}\right.$ and

$404 Q_{I r}$; dashed grey curve) using the direct model without lateral flows, and the simulated lateral

405 hydrograph $\left(Q_{A f}\right.$ and $Q_{A}$; dotted red curve) using the inverse model. Both soil saturation 406 index (HU2 >58) and groundwater levels ( $\mathrm{GW}>-15 \mathrm{~m}$ AGL) were saturated before the 407 beginning of the flood. The discharge analysis shows a strong attenuation of the flood 408 hydrograph along the reach, halving the peakflow from $26.8 \mathrm{~m}^{3} / \mathrm{s}\left(Q x_{I}\right)$ to $13.7 \mathrm{~m}^{3} / \mathrm{s}\left(Q x_{O}\right)$. 409 Before the flood, lateral inflow $\left(Q_{A}(t)\right)$ was $3.7 \mathrm{~m}^{3} / \mathrm{s}$; but during the flood it became negative.

410 This may be interpreted as a continuous contribution of lateral baseflow hidden by occasional 411 high losses in the flood component. Using the minimum values of the lateral flood

412 component, we can quantify the maximum intensity of lateral outflow $Q n_{A f}$ as $-6.8 \mathrm{~m}^{3} / \mathrm{s}$. The 413 peakflow attenuation due to outflow (losses+overbank flow) $E_{A}$ is $-6.6 \mathrm{~m}^{3} / \mathrm{s}$ and the 414 attenuation due to diffusion $E_{D}$ is $-9.2 \mathrm{~m}^{3} / \mathrm{s}$, leading to a total peakflow attenuation $E$ of $415 \quad 15.8 \mathrm{~m}^{3} / \mathrm{s}$.

416 Analysis of this single flood event shows that, despite lateral baseflow, the outflow associated 417 to the flood component can be quantified. As outflow by overbank flow may occur during the 418 highest discharge, outflow by river losses is probably continuous as long as the stream flows 419 at the input station. This suggests that losses are compensated by highest baseflow discharge 420 during recession periods, leading to under-estimating their real values. The other interesting 421 point is that we can compare peakflow attenuation by hydraulic processes (diffusion) and by 422 outflow (river loss+overbank flow), quantifying it (for a given parameterization set) equal to $42357 \%$ and $43 \%$, respectively.

\section{$424 \quad$ 4.2.2 Distribution of model parameters}

425 Following the above example, the model was applied to the 33 main flood events (Table 1), 426 using the parameterization strategy presented in Section 2.5. Several values of $D$ were 427 selected for optimizing the $C$ parameter, for inputting phase peakflows of the routed input 
hydrograph $\left(Q_{I r}\right)$ and of the output one $\left(Q_{O}\right)$. Figure 9 shows $C$ distribution using boxplots for

429 five $D$ values of $500,1000,2500,5000$, and $10,000 \mathrm{~m}^{2} / \mathrm{s}$, which is the classic range for 430 streams and rivers (Todini, 1996), such as in our study, knowing that $D$ increases with the size 431 of the river. Boxplot analysis shows that $C$ values range between 0.1 and $0.4 \mathrm{~m} / \mathrm{s}$ with a 432 relative small variability for a given $D$. The higher the $D$, the lower will be the range of $C$ 433 values from 0.35 to $0.11 \mathrm{~m} / \mathrm{s}$. As shown in the sensitivity analysis (Section 2.4 above), a 434 lower limit of $C$ values to almost $0.15 \mathrm{~m} / \mathrm{s}$ is observed for $D$ values above $2500 \mathrm{~m}^{2} / \mathrm{s}$. 435 Knowing that lateral flows are highly sensitive to $C$ values and less so to $D$ values, various 436 parameterization sets will be tested in the following section.

\section{$437 \quad 4.3$ Quantification of peakflow attenuation}

\section{$438 \quad$ 4.3.1 Assessment of lateral outflow}

439 In order to quantify outflow during floods, we express the maximum lateral outflow intensity 440 as a function of the input peakflow. Figure 10 presents $Q n_{A f}$ (i.e. maximum losses as negative 441 values attributed to outflow) vs. $Q x_{I f}$ for all the 33 flood events and for five calibration 442 strategies that vary $D$ (and the corresponding optimized $C$ ) from 500 to $10,000 \mathrm{~m}^{2} / \mathrm{s}$; dark blue 443 colours refer to the lowest $D$ values. The first result confirms that outflow for the flood 444 component is simulated for all flood events, regardless of input peakflow. This means that 445 lateral outflow intensities of the fast component are systematically higher than potential 446 lateral inflow values during the flood, i.e. flood flow from karst springs and tributaries, or 447 surface runoff. As expected, the second result confirms that, globally, the lateral outflow 448 intensity is higher for a lower $D$. Outflow increases with increasing input peakflow, but the 449 relationship stabilizes when $Q x_{I f}>12 \mathrm{~m}^{3} / \mathrm{s}$, very close to the threshold value of $14 \mathrm{~m}^{3} / \mathrm{s}$ for 450 starting overbank flow when considering peakflow of the total discharge $Q x_{I}\left(Q x_{I}=Q x_{I f}+Q_{I b}\right)$.

451 For $D=500 \mathrm{~m}^{2} / \mathrm{s}, Q n_{A f}$ reaches a ceiling of $\sim 9 \mathrm{~m}^{3} / \mathrm{s}$, against $7 \mathrm{~m}^{3} / \mathrm{s}$ for $D=1000 \mathrm{~m}^{2} / \mathrm{s}$ and $2 \mathrm{~m}^{3} / \mathrm{s}$ 452 for the highest $D$ value of $10,000 \mathrm{~m}^{2} / \mathrm{s}$. 
The influence of the initial karst saturation level on outflow intensity has been tested, and any concluding results were highlighted to validate this hypothesis. Consequently, input peakflow seems to be the main driver of outflow intensity. An interesting result is that when discharge is below the overbank flow threshold ( $\left.Q x_{I f}<12 \mathrm{~m}^{3} / \mathrm{s}\right)$, outflow is mainly due to river losses, following a linear relationships between $Q n_{A f}$ and $Q x_{I f}$. Depending upon the parameterization strategy, these river losses may reach high values of up to $9 \mathrm{~m}^{3} / \mathrm{s}$, corresponding to half of the peakflow at the input station. When discharge exceeds this threshold, the highest discharge outflow ceiling may be explained by a limitation of the infiltration rate into the stream bed, due to a ceiling of the water-level increase in the river bed when overbank flow occurs.

\subsubsection{Factors influencing peakflow attenuation}

Two phenomena participate in peakflow attenuation $(E)$ : hydraulic processes due to flood wave diffusivity $\left(E_{D}\right)$ and hydrological processes due to outflow $\left(E_{A}\right)$ (cf. Eq. 13). To quantify their respective roles, Figure 11 presents the $E_{A} v s . E_{D}$ relationships for the same five parameterization strategies as in Figure 10. We see that $E_{D}$ ranges between -18.0 to $-0.5 \mathrm{~m}^{3} / \mathrm{s}$ whereas $E_{A}$ ranges between -9 to $4.0 \mathrm{~m}^{3} / \mathrm{s}$. As expected, the higher the $D$ (light blue colour), the higher the $\left|E_{D}\right|$ values (negative in the graph since $E_{D}$ is inevitably an attenuation of peakflow). Except for cases with the lowest $D$ values $\left(D=500 \mathrm{~m}^{2} / \mathrm{s}\right)$, and some cases with $D=1000 \mathrm{~m}^{2} / \mathrm{s}$ (dark blue colour, Figure 11), the points lie below the $E_{D}=E_{A}$ line, i.e. attenuation due to diffusivity is often higher than that due to outflow. It is interesting to note that when $D$ is high and thus $\left|E_{D}\right|$ is high, $E_{A}$ is positive (lateral flow became inflow) while being below the $E_{D}=-E_{A}$ line. This means that in these cases, despite flood amplification due to lateral inflow, peakflow attenuation is finally observed because the effect of high diffusivity overtakes it.

These simulation tests replicate a wide range of classic stream and river $D$ values found in the literature. Finally, we should evaluate the proportion of $E_{D}$ and $E_{A}$ for the theoretical range of 
$D$, calculated with the following formula proposed by Chow (1959) that considers simple

479 network descriptors: $D=\bar{Q} /(2 \times$ slope $\mathrm{x}$ width $)$, where $\bar{Q}$ is the mean flow discharge for a

480 rectangular section. Varying the mean slope of the river from 0.0010 to 0.0015 , the mean river 481 width from 5 to $10 \mathrm{~m}$, and $\bar{Q}$ from 5 to $20 \mathrm{~m}^{3} / \mathrm{s}, D$ ranges between 250 and $2000 \mathrm{~m}^{2} / \mathrm{s}$, over a 482 quite small range of values compared to the tested ones (500 to $\left.10,000 \mathrm{~m}^{2} / \mathrm{s}\right)$. In this 483 theoretical case, $E_{D}$ and $E_{A}$ are roughly equal according to Figure 11, but this result should be 484 taken with care due to the high spatial variability of channel properties along the Iton River.

485 In summary, these results show that, in the case of low $D$ values, peakflow attenuation is 486 equally due to diffusion and to outflow, but in cases with high $D$ values, most of this 487 attenuation is caused by diffusion. They also show that, despite lateral inflow in the case of 488 highest $D$ values, these contributions are compensated by a strong attenuation due to flood 489 wave routing.

\section{Discussion}

5.1 On the interest of using a diffusive wave model to assess peakflow attenuation and/or amplification

Although aquifer's recharge by river losses can attenuate floods in arid/Mediterranean environment (Sorman et al., 1997; Hughes \& Sami, 1992; Lange, 2005; Dahan et al., 2007; Vázquez- Suñé et al., 2007) or in karst basins (Jourde et al., 2013; Charlier et al., 2015b; Brunet and Bouvier, 2017), we cannot neglect hydraulic diffusion processes when we are

497 interested in peakflow forecasting. In the case of permeable basins, our results show that, 498 despite the presence of an infiltration zone in the river bed with significant losses (several $499 \mathrm{~m}^{3} / \mathrm{s}$ ), peakflow attenuation is mainly related to diffusion of the flood wave. This raises the 500 question of the mechanisms favouring such attenuation, which may be related to the 501 meandering morphology of the drainage network, as well as to the zones of temporary storage 502 for highest flood events (Moussa \& Cheviron, 2015). 
503 Our example shows the added value of using a diffusive model—combining direct and

504 inverse problem approaches - for better understanding and quantifying SW/GW interactions 505 during floods, and which deserves to be tested on other types of basins where significant 506 lateral losses and/or gains are observed (Martin \& Dean, 2001; Ruehl et al., 2006; Payn et al., 507 2009). For instance, the inverse DWE model has also been used for investigating lateral flow 508 in underground karst conduits, and for defining the exchanges between conduits and the 509 fissured matrix (Cholet et al., 2017). In parallel to these considerations that promote the model 510 as a tool for diagnosing SW/GW exchanges at different scales, our results highlight the 511 inaccuracies that can be generated by using non-diffusive models, as is frequently the case for 512 flood modelling (see review in Singh, 2002) and for karst basins (Bailly-Comte et al., 2012; 513 Dvory et al., 2018). Our results are coherent with Naulin's work (2012) in the Cévennes 514 region (southern France), who showed that DWE was more suitable in lowland areas, 515 including karst formations, than in mountains with less permeable hard-rock formations.

\section{$516 \quad 5.2$ Surface-water / groundwater interactions in permeable basins}

\section{$517 \quad$ 5.2.1 River losses and overbank flow}

518 The relationship between lateral outflow and input peakflow has established a function of 519 river losses that improves the understanding of SW/GW interactions in permeable basins. In 520 fact, below the discharge threshold for overbank flow, outflow is mainly generated by losses 521 that account in our case for several $\mathrm{m}^{3} / \mathrm{s}$ during a flood. Although this process is well known 522 in many catchments when studying low water-level periods, it is generally not considered 523 during flood events, because inflow conceals it. Despite some works on infiltrating floodwater 524 in basins characterized by disconnected river-aquifer systems (Hughes \& Sami, 1992; Lange, 525 2005; Dahan et al., 2007; Vázquez- Suñé et al., 2007), the estimation of infiltration rate 526 during the flood (i.e. at a high temporal resolution) is generally disregarded. Thus, our study 
brings a relevant approach to help quantify the loss intensities as well as the recharge rate of

528 the underlying aquifers.

529 Outflow due to river losses is an important process as it may represent up to half of peakflow

530 in models, depending upon the parameterization strategy. The estimated value loss of several

$531 \mathrm{~m}^{3} / \mathrm{s}$ is important, but not exceptional as it is coherent with observations made on other

532 ephemeral karst rivers in southern France (Ladouche et al. 2002, 2004), or in the Jura

533 Mountains (Charlier et al., 2014). The linear relationship between outflow intensity and input

534 peakflow (below the overbank flow threshold) argues for the control of loss rate by water

535 height in the river. This implies that the aquifer fed by the losses is disconnected with the

536 river, agreeing with the absence of influence of groundwater level on this relationship.

537 The ceiling of outflow intensity with the increase of discharge into the river is most probably 538 explained by the occurrence of overbank flow, knowing that flood plain attenuation can play a 539 key role on the modification of hydrograph shape (Sholtes \& Doyle, 2011; Valentova et al., 540 2010; Rak et al., 2016; Fleischmann et al., 2018). Indeed in the study case, outflow on the 541 flood plain appears to be an important process of peakflow attenuation for the highest floods, 542 since the increase in infiltration with an increased input peakflow is stopped (Figure 10). 543 Another concept may explain this outflow ceiling: several studies of karst hydrology reported 544 a limitation of infiltration during rainfall events due to small void diameters or constricted 545 conduits at depth (Bonacci, 2001; Bailly-Comte et al., 2009). However, such a process 546 requires specific monitoring that fell outside the scope of our study.

\section{$547 \quad 5.2 .2 \quad$ Loss and gain in river reaches}

548 The specific features of the studied river, including both loss and gain reaches, render an 549 analysis of lateral exchanges difficult. The occurrence of both out- and in-flow in some 550 reaches has been conceptualized as hydrologic turnover (Covino et al. 2011; Mallard et al., 551 2014) in simultaneous loss and gain reaches. This pattern was highlighted both in chalk 
catchments, where it was found that groundwater flooding consists of a combination of

553 intermittent stream discharge and anomalous springflow (Hughes et al., 2011), and in karst

554 rivers characterized by successive loss and gain reaches from a multi-layered aquifer in deep

555 canyons (Charlier et al., 2015b). Improving the understanding of lateral exchange during 556 floods, our modelling approach opens a novel way to help deciphering the various 557 contributions of loss and gain.

\section{$558 \quad 5.3$ Saturation state in a karst catchment: soil moisture vs. aquifer storage}

559 An influence of the aquifer-saturation state on peakflow attenuation is observed in the karst 560 part of the catchment. This agrees with several papers on the exceptional groundwater 561 flooding of 2000-2001, in karstified chalk areas of northern Europe (Finch et al., 2004; 562 Pinault et al., 2005; Hughes et al., 2011; Morris et al., 2015; Thiéry et al. 2018). However, we 563 did not see this influence on the relationship between lateral outflow intensity and input 564 peakflow on the flood component, as might have been expected. This means that aquifer 565 saturation probably influences the baseflow component, which increases strongly in the karst 566 reach (Figure 5). Even if river losses recharge the underlying aquifer, which in turn feed the 567 river downstream, these results are not contradictory. In fact, losses are controlled by the 568 infiltration zone, which is never fully saturated, whereas baseflow is linked to groundwater 569 levels (Figure 6).

570 Comparing this pattern with classic catchment hydrology, it is interesting to note that the soil 571 moisture index HU2 (which only reflects the supposed behaviour of the soil cover) doesn't 572 influence the runoff-runoff relationships in our case, even for events for which the saturation 573 state of the aquifer is low. This is finally consistent with the fact that, with lateral 574 contributions being mainly of underground origin, it is the initial antecedent saturation of the 575 aquifer that is the best indicator of the saturation state of the catchment. This result reflects the 576 specificities of karst catchments as compared to other types of catchment. Most production 
577 functions in hydrological models are designed to consider the role of soil moisture (e.g. 578 Horton, 1933; Philip, 1957; SCS, 1972; Morel-Seytoux, 1978). Our results show, however, 579 that such models cannot be generalized for carbonate basins with significant SW/GW 580 interactions, when neglecting deep infiltration and groundwater storage in the bedrock.

\section{$581 \quad 5.4 \quad$ Implications for flood forecasting}

582 On the basis of our results and the available data, several insights can be proposed for reliable

583 flood forecasting in permeable basins including karst as well as more generally ephemeral 584 streams. As a karst aquifer is a complex hydrogeological medium, an analysis of its 585 hydrogeological behaviour and its role in runoff at the basin scale is an essential prerequisite. 586 Our first recommendation is not to neglect the influence of hydraulics (diffusivity) on flood 587 routing. For example, floodplains or karst canyons promote meandering networks that are 588 supposed to be an exacerbating factor in wave diffusion. Knowing this, the main risk in 589 forecasting is thus to significantly over-estimate peakflow when applying non diffusive flood590 routing models. The second recommendation is to account for river loss in the modelling 591 approach if flood analysis shows significant outflow. The relationship we propose between 592 input peakflow and lateral flow intensity can serve as a basis for such an infiltration function 593 to be implemented in a model. The third recommendation is to use groundwater level as an 594 index of basin saturation for initializing hydrological models. This has to be considered in 595 preference to a soil moisture index, which appears inappropriate for such a basin with fast 596 infiltration at depth.

\section{Conclusions}

598 We propose a framework for quantifying peakflow attenuation and/or amplification in a river, 599 based on defining lateral flow during floods in the case of a highly permeable basin that 600 favours surface-water/groundwater interactions. The novelty of our research is the use of the 601 inverse problem of the DWE proposed by Moussa (1996) to simulate a lateral flow 
602 hydrograph in a river reach draining karst formations (Normandy, France), knowing the

603 hydrographs from both upstream and downstream gauging stations. Application of the model

604 to several flood events of various intensity shows that, despite a high groundwater

605 contribution to the baseflow component, the peakflow was strongly attenuated. Our approach

606 was designed to differentiate between attenuation generated by wave diffusion and that

607 generated by outflow related to river loss and overbank flow.

608 Our results provide new insight in flood routing processes in a karst context and more

609 generally in permeable basins favouring ephemeral streams and disconnected river-aquifer

610 systems. First, the model restituted the global dynamics of lateral flow, given information on

611 the hydrological processes involved. Second, we could propose a relationship quantifying

612 outflow intensity as a function of peakflow discharge at the upstream gauging station. Based

613 on previous experimental work investigating the hydrological processes at the origin of loss

614 and gain in rivers, we could highlight the importance of river losses and then of overbank

615 flow for highest flood events. Third, as lateral flow is characterized for unsteady-state

616 conditions, the relative contribution of outflow compared to attenuation due to diffusion was

617 characterized for several sets of model parameterization, allowing interpretations according to

618 parameter sensitivity.

619 In a more global way, our approach deserves to be tested as a diagnostic tool before applying 620 hydrological models for flood forecasting in permeable - karst - basins. The conclusions 621 provided by our model can help modellers in selecting the best tool in terms of hydrological 622 processes to be simulated as well as of parameterization strategy.

\section{Data Availability Statement}

624 The datasets used in this article can be obtained by contacting Jean-Baptiste Charlier 625 (j.charlier@brgm.fr). 


\section{Acknowledgments}

627 We warmly thank Cédric Zaniolo and Stéphane Piney of the "Service de Prévision des Crues

628 (SPC)" at Rouen for fruitful discussions that helped improving the paper. The work was

629 funded by the French Governmental Administration for Risk Prevention (DGPR), the Service

630 Central d'Hydrométéorologie et d'Appui à la Prévision des Inondations (SCHAPI), and the

631 French Geological Survey (BRGM).

632

\section{References}

634 ADES (2015). portail ADES, http://www.ades.eaufrance.fr/ (data exported in July 2015).

635 Bailly-Comte, V., Jourde, H., \& Pistre, S. (2009). Conceptualization and classification of 636 groundwater-surface water hydrodynamic interactions in karst watersheds: Case of the karst 637 watershed of the Coulazou River (southern France), Journal of Hydrology, 376(3-4): 456638 462, doi:10.1016/j.jhydrol. 2009.07.053.

639 Bailly-Comte, V., Borrell-Estupina, V., Jourde, H., \& Pistre, S. (2012). A conceptual 640 semidistributed model of the Coulazou River as a tool for assessing surface water-karst 641 groundwater interactions during flood in Mediterranean ephemeral rivers, Water Resources 642 Research, 48, W09534, doi:10.1029/2010wr010072.

643 Banque Hydro (2015). http://www.hydro.eaufrance.fr/ (data exported in February 2015).

644 Bates, P.D., \& De Roo, A.P.J. (2000). A simple raster-based model for flood inundation 645 simulation. Journal of Hydrology 236, 54-77

646 Bonacci, O. (2001). Analyses of the maximum discharge of karst springs, Hydrogeological 647 Journal, 9, 4, 328-338. 
648 Bonacci, O., Ljubenkov, I., \& Roje-Bonacci, T. (2006). Karst flash floods: An example from 649 the Dinaric karst (Croatia), Natural Hazards and Earth System Sciences, 6, 195-203, 650 doi:10.5194/nhess-6-195-2006.

651 Brunet, P., \& Bouvier, C. (2017). Retour d'expérience sur la crue du 12 septembre 2015 à 652 Lodève (Hérault, France) : influence du karst sur les débits de pointe de crue. La Houille 653 Blanche, 3: 39-46. DOI :10.1051/lhb/2017020.

654 Camarasa Belmonte, A.M., \& Segura Beltrán, F. (2001). Flood events in Mediterranean 655 ephemeral streams (ramblas) in Valencia region, Spain. Catena, 45, 229-249. 656 doi.org/10.1016/S0341-8162(01)00146-1

657 Charlier, J.-B., Moussa, R., Cattan, P., Cabidoche, Y.M., Voltz, M. (2009). Modelling runoff 658 at the plot scale taking into account rainfall partitioning by vegetation: application to 659 stemflow of banana (Musa spp.) plant. Hydrology and Earth System Sciences, 13, 2151-2168, 660 doi: 10.5194/hess-13-2151-2009.

661 Charlier, J.-B., Desprats, J.-F., \& Ladouche, B., (2014). Appui au SCHAPI 2014 - Module 1 662 - Rôle et contribution des eaux souterraines d'origine karstique dans les crues de la Loue à 663 Chenecey-Buillon, BRGM/RP-63844-FR report, 109p. http://infoterre.brgm.fr/rapports/RP664 63844-FR.pdf (accessed April 2018).

665 Charlier, J.-B., David, P.-Y., Lanini, S. \& Desprats, J.-F. (2015a). Appui au SCHAPI 2015 666 Module 1 - Rôle et contribution des eaux souterraines d'origine karstique aux crues des 667 bassins normands de l'Iton et de l'Orbiquet. BRGM RP-65570-FR report, $84 \mathrm{p}$. 668 http://infoterre.brgm.fr/rapports/ RP-65570-FR.pdf (accessed April 2018).

669 Charlier, J.-B., Moussa, R., Bailly-Comte, V., Danneville, L., Desprats, J.-F., Ladouche, B., \& 670 Marchandise, A. (2015b). Use of a flood-routing model to assess lateral flows in a karstic 671 stream: implications to the hydrogeological functioning of the Grands Causses area (Tarn 
672 River, Southern France), Environmental Earth Sciences, 74: 7605-7616, DOI 673 10.1007/s12665-015-4704-0.

674 Chen, Z., Auler, A. S., Bakalowicz, M., Drew, D., Griger, F., Hartmann, J., Jiang, G., 675 Moosdorf, N., Richts, A., Stevanovic, Z., Veni, G., \& Goldscheider, N., (2017). The World 676 Karst Aquifer Mapping project: concept, mapping procedure and map of Europe. 677 Hydrogeological Journal, 25: 771-785. DOI 10.1007/s10040-016-1519-3

678 Cholet, C., Charlier, J.-B., Moussa, R., Steinmann, M., \& Denimal, S., (2017). Assessing 679 lateral flows and solute transport during floods in a conduit-flow-dominated karst system 680 using the inverse problem for the advection-diffusion equation, Hydrology and Earth System 681 Sciences, 21: 3635-3653. DOI: 10.5194/hess-21-3635-2017.

682 Chow, V. T. (1959). Open-Channel Hydraulics. McGraw-Hill, New York. 680p.

683 Cimorelli, L., Cozzolino, L., Della Morte, R., \& Pianese, D. (2014). Analytical solutions of 684 the linearized parabolic wave accounting for downstream boundary condition and uniform 685 lateral inflows, Advances in Water Resources, 63, 57-76, DOI: 686 /10.1016/j.advwatres.2013.11.003.

687 Cimorelli, L., Cozzolino, L., D'Aniello A., \& Pianese, D. (2018). Exact solution of the Linear 688 Parabolic Approximation for flow-depth based diffusive flow routing, Journal of Hydrology 689 563,620-632, DOI: /10.1016/j.jhydrol.2018.06.026.

690 Covino, T. P., McGlynn, B. L., \& Mallard, J. M. (2011). Stream-groundwater exchange and 691 hydrologic turnover at the network scale, Water Resources Research, 47, W12521, 692 doi:10.1029/2011WR010942

693 Dahan, O., Shani, Y., Enzel, Y., Yechieli, Y., \& Yakirevich, A., (2007). Direct measurements 694 of floodwater infiltration into shallow alluvial aquifers. J. Hydrol. 344, 157-170. 
David, P.-Y., Meire, B., Cary, L., Charlier, J.-B., Lemesnil, M., Ladouche, B., Richard, M., \&

696 Yecora Zorzano, L. (2016). Étude du fonctionnement et de la vulnérabilité du bassin versant

697 de l'Iton - État des connaissances, analyse des données et premiers résultats. BRGM/ $R P$ 698 65618-FR report, 401 p. http://infoterre.brgm.fr/rapports/ RP-65618-FR.pdf (accessed April 699 2018).

700 Dvory, N. Z., Ronen, A., Livshitz, Y., Adar, E., Kuznetsov, M., \& Yakirevich, A. (2018). 701 Quantification of groundwater recharge from an ephemeral stream into a mountainous karst 702 aquifer. Water, 10(1), 79. doi:10.3390/w10010079

703 Finch, J. W., Bradford, R. B., \& Hudson, J. A. (2004). The spatial distribution of groundwater 704 flooding in a chalk catchment in southern England. Hydrological Processes, 18: 959-971. 705 doi:10.1002/hyp.1340

706 707 708 709 710

Fleischmann, A. S., R. C. D. Paiva, W. Collischonn, M. V. Sorribas, \& P. R. M. Pontes (2016), On river- floodplain interaction and hydrograph skewness, Water Resour. Res., 52, 7615-7630, doi:10.1002/2016WR019233.

Fleury, P., Maréchal, J. C., \& Ladouche, B. (2013). Karst flash-flood forecasting in the city of Nîmes (southern France). Engineering Geology, 164: 26-35. doi:10.1016/j.enggeo.2013.06.007

Gill, L. W., Naughton O., \& Johnston, P. M. (2013). Modelling a network of turloughs in lowland karst. Water Resources Research, 49(6):3487-3503.

Gustard, A., A. Bullock, \& J.M. Dixon. (1992). Low flow estimation in the United Kingdom. Report no. 108. Wallingford, Oxfordshire, UK: Institute of Hydrology

Habets F., A. Boone, J. L. Champeaux, P. Etchevers, L. Franchisteguy, E. Leblois, E. Ledoux, P. Le Moigne, E. Martin, S. Morel, J. Noilhan, P. Q. Segui, F. Rousset-Regimbeau, \& P. 
717 Viennot (2008). The SAFRAN-ISBA-MODCOU hydrometeorological model applied over

718 France, Journal of Geophysical Research., 113, D06113, doi:10.1029/2007JD008548.

719 Habets F., Gascoin S., Korkmaz S., Thiéry D., Zribi M., Amraoui N., Carli M., Ducharne A.,

720 Leblois E., Ledoux E., Martin E., Noilhan J., Ottl’e C. \& Viennot P. (2010). Multi-model 721 comparison of a major flood in the groundwater-fed basin of the Somme River (France).

722 Hydrology and Earth System Sciences, 14:99-117.

723 Hayami, S., (1951). On the propagation of flood waves. Disaster Prevention Research 724 Institute Bulletin, 1: 1-16.

725 Horton, R., (1933). The role of infiltration in the hydrologic cycle. American Geophysical 726 Union Transactions, 14, 446-460

727 House, A. R., Thompson, J. R., Sorensen, J. P. R., Roberts, C., \& Acreman, M. C. (2016). 728 Modelling groundwater/surface water interaction in a managed riparian chalk valley wetland. 729 Hydrological Processes, 30: 447-462. doi: 10.1002/hyp.10625.

730 Hughes DA, \& Sami K (1992). Transmission losses to alluvium and associated moisture 731 dynamics in a semiarid ephemeral channel system in southern Africa. Hydrol. Process. 6:45$732 \quad 53$

733 Hughes, A. G., Vounaki, T., Peach, D.W., Ireson, A.M., Jackson, C.R., Butler, A.P., 734 Bloomfield, J.P., Finch, J. \& Wheater, H.S. (2011). Flood risk from groundwater: examples 735 from a Chalk catchment in southern England. Journal of Flood Risk Management, 4: 143736 155. doi: 10.1111/j.1753-318X.2011.01095.x

737 Hunter, N. M., Bates, P.D., Horritt, M.S., \& Wilson, M.D., (2007). Simple spatially738 distributed models for predicting flood inundation: a review. Geomorphology 90, 208-225. 
739 Jothityangkoon, C., \& M. Sivapalan (2003). Towards estimation of extreme floods:

740 Examination of the roles of runoff process changes and floodplain flows, J. Hydrol., 281(3),

741 206-229. doi.org/10.1016/S0022-1694(03)00237-3

742 Jourde, H., Lafare, A., Mazzilli, N., Belaud, G., Neppel L., Doerfliger, N., \& Cernesson, F. 743 (2013). Flash flood mitigation as a positive consequence of anthropogenic forcings on the 744 groundwater resource in a karst catchment. Environmental Earth Sciences, 71:573-583. 745 doi:10.1007/s12665-013-2678-3.

746 Korkmaz, S., Ledoux, E., \& Onder, H. (2009). Application of the coupled model to the 747 Somme river basin. Journal of Hydrology, 366 (1-4): 21-34, 748 https://doi.org/10.1016/j.jhydrol.2008.12.008.

749 Ladouche, B., Dörfliger, N., Pouget, R., Petit, V., Thiéry, D., Golaz, C., Bakalowicz, M., 750 Lachassagne, P., Pinault, J.-L., Durand, V., \& Cubizolles, J., (2002). Caractérisation du 751 fonctionnement des systèmes karstiques nord-montpelliérains - Rapport du Programme 752 Buèges 1999-2001. BRGM/RP-51584-FR report, http://infoterre.brgm.fr/rapports/RP-51584$753 \quad$ FR.pdf (accessed April 2018).

754 Ladouche, B., Dörfliger, N., Izac, J.-L., Cubizolles, J., Le Strat, P., Du Couedic, C., Aunay, 755 B., \& Thomson, P., (2004). Évaluation des ressources en eau des Corbières. Phase 1 : 756 Synthèse de la caractérisation des systèmes karstiques des Corbières Orientales. Vol. 2 757 Caractérisation géologique et hydrogéologique du système karstique du "synclinal du Bas758 Agly". BRGM/RP-52919-FR report, http://infoterre.brgm.fr/rapports/RP-52919-FR.pdf 759 (accessed April 2018).

760 Ladouche, B., Maréchal, J.-C., \& Dörfliger, N., (2014). Semi-distributed lumped model of a 761 karst system under active management. Journal of Hydrology, 509, 215-230. 762 doi:/10.1016/j.jhydrol.2015.02.003. 
763 Lange, J. (2005). Dynamics of transmission losses in a large arid stream channel, Journal of 764 Hydrology, $306(1-4): 112-126$.

765 Lanini, S., Caballero, Y., Seguin, J.-J., \& J.-C. Maréchal, (2016). ESPERE-A Multiple766 Method, Groundwater. 54(2): 155-156, doi: 10.1111/gwat.12390.

767 Lopez-Chicano, M., Calvache, M.L., Martin-Rosales, \&W., Gisbert J (2002). Conditioning 768 factors in flooding of karstic poljes - the case of the Zafarraya polje (South Spain). Catena 769 49(4):331-352.

770 Mallard, J., B. McGlynn, \& T. Covino (2014). Lateral inflows, stream-groundwater exchange, 771 and network geometry influence stream water composition, Water Resources Research, 50, 772 4603-4623, doi:10.1002/2013WR014944.

773 Maréchal, J.C., Ladouche, B., Dörfliger, N. (2008). Karst flash flooding in a Mediterranean 774 karst, the example of Fontaine de Nîmes. Engineering Geology, 99(3-4):138-146. 775 doi:10.1016/j.enggeo.2007.11.013.

776 Martin, J. B. \& Dean, R.W. (2001). Exchange of water between conduits and matrix in the 777 Floridan aquifer, Chemical Geology, 179: 145-165, https://doi.org/10.1016/S0009$778 \quad 2541(01) 00320-5$.

779 Morel-Seytoux, H., 1978. Derivation of equations for variable rainfall infiltration. Water $780 \quad$ Resources Research, 14 (4), 561-568.

781 Morris, S.E., Cobby, D., Zaidman, M. \& Fisher, K. (2015). Modelling and mapping 782 groundwater flooding at the ground surface in Chalk catchments. Journal of Flood Risk 783 Management. doi: 10.1111/jfr3.12201

784 Moussa R. (1996). Analytical Hayami solution for the diffusive wave flood routing problem 785 with lateral inflow. Hydrological Processes 10(9): 1209-1227. 
786 Moussa, R. \& Bocquillon, C. (1996a) Criteria for the choice of flood routing methods in 787 natural channels, Journal of Hydrology, 186: 1-30.

788 Moussa R., \& Bocquillon C. (1996b). Algorithms for solving the diffusive wave flood routing 789 equation. Hydrological Processes 10 (1): 105-124.

790 Moussa R., \& Bocquillon C. (2009). On the use of the diffusive wave for modelling extreme 791 flood events with overbank flow in the floodplain. Journal of Hydrology, 374: 116-135, 792 doi:10.1016/j.jhydrol.2009.06.006.

793 Moussa R., \& Majdalani S. (2019). Evaluating lateral flow in an experimental channel using 794 the diffusive wave inverse problem. Advances in Water Resources 127: 120-133. 795 Doi:10.1016/j.advwatres.2019.03.009.

796 Moussa, R., Voltz M., \& Andrieux, P., (2002). Effects of the spatial organization of 797 agricultural management on the hydrological behaviour of a farmed catchment during flood 798 events. Hydrological Processes 16: 393-412. doi: 10.1002/hyp.333.

799 Moussa, R., \& Cheviron, B. (2015). Modeling of Floods - State of the Art and Research 800 Challenges. In: Rowiński P., Radecki-Pawlik A. (eds) Rivers - Physical, Fluvial and 801 Environmental Processes. GeoPlanet: Earth and Planetary Sciences. Springer, Cham. doi: 802 10.1007/978-3-319-17719-9_7.

803 Naughton, O., Johnston, P.M., Gill. L.W., (2012). Groundwater flooding in Irish karst: The 804 hydrological characterisation of ephemeral lakes (turloughs). Journal of Hydrology. 470-471: $805 \quad 82-97$.

806 Naulin, J.-P. (2012). Modélisation hydrologique distribuée pour la prévision des coupures de 807 routes par inondation, application au département du Gard. PhD Thesis, Ecole Centrale de 808 Nantes, 290p. 
809 Payn, R. A., Gooseff, M. N., McGlynn, B. L., Bencala, K. E., \& Wondzell, S. M. (2009).

810 Channel water balance and exchange with subsurface flow along a mountain headwater

811 stream in Montana, United States, Water Resources Research, 45, W11427,

812 https://doi.org/10.1029/2008WR007644.

813 Philip, J., 1957. The theory of infiltration: 4. Sorptivity and algebraic infiltration equations.

814 Soil Science 84 (3), 257-264.

815 Pinault, J.-L., N. Amraoui, \& Golaz C. (2005). Groundwater-induced flooding in macropore-

816 dominated hydrological system in the context of climate changes, Water Resources Research,

817 41, W05001, doi:10.1029/2004WR003169.

818 Ponce, V.M., (1990). Generalized diffusive wave equation with inertial effects. Water 819 Resources Research 26 (5), 1099-1101.

820 Price, M., Low, R.G., \& McCann, C. (2000). Mechanisms of water storage and flow in the 821 unsaturated zone of the Chalk aquifer. Journal of Hydrology 233:54-71.

822 Rak, G., Kozelj, D. \& Steinman, F. (2016). The impact of floodplain land use on flood wave 823 propagation. Nat Hazards, 83: 425. doi.org/10.1007/s11069-016-2322-0

824 Robins N. S., \& Finch J. W. (2012). Groundwater flood or groundwater-induced flood? 825 Quarterly Journal of Engineering Geology and Hydrogeology, 45:119-122. DOI: $826 \quad 10.1144 / 1470-9236 / 10-040$.

827 Ruehl, C., Fisher, A. T., Hatch, C., Huertos, M. L., Stemler, G., \& Shennan, C. (2006). 828 Differential gauging and tracer tests resolve seepage fluxes in a strongly-losing stream, 829 Journal of Hydrology, 330:235-248, https://doi.org/10.1016/j.jhydrol.2006.03.025.

830 Sholtes J.S., \& Doyle M.W. (2011) Effect of channel restoration on flood wave attenuation. J $831 \quad$ Hydraul Eng 137(2):196-208 
832 Singh, V. P. (2002). Is hydrology kinematic?, Hydrological Processes, 16, 667-716, doi: $83310.1002 /$ hyp.306.

834 Soil Conservation Service-USDA, (1972). Estimation of direct runoff from storm rainfall, 835 National Engineering Handbook. Section 4-Hydrology, 10.1-10.24.

836 Sorman, A.U., Abdulrazzak, M.J., \& Seytoux, M.H.J. Groundwater recharge estimation from 837 ephemeral streams. case study: Wadi Tabalah, Saudi Arabia. Hydrol. Process. 1997, 11, $838 \quad 1607-1619$.

839 Thiéry, D., Amraoui, N., \& Noyer, M.-L., (2018). Modelling flow and heat transfer through 840 unsaturated chalk - Validation with experimental data from the ground surface to the aquifer. 841 Journal of Hydrology, 556: 660-673. doi.org/10.1016/j.jhydrol.2017.11.041

842 Todini E. (1996). The ARNO rainfall-runoff model. Journal of Hydrology, 175: 339-382.

843 Trigg, M.A., Wilson, M.D., Bates, P.D., Horritt, M.S., Alsdorf, D.E., Forsberg, B.R., \& Vega, 844 M.C., (2009). Amazon flood wave hydraulics. Journal of Hydrology 374(1):92-105

845 Upton, K. A., \& Jackson, C. R., (2011). Simulation of the spatio-temporal extent of 846 groundwater flooding using statistical methods of hydrograph classification and lumped 847 parameter models. Hydrological Processes 25: 1949-1963. DOI: 10.1002/hyp.7951.

848 Valentova J, Valenta P, \&Weyskrabova L (2010) Assessing the retention capacity of a 849 floodplain using a 2D numerical model. J Hydrol Hydromech 58(4):221-232

850 Vázquez- Suñé, E., Capino, B., Abarca, E., \& Carrera, J. (2007). Estimation of Recharge 851 from Floods in Disconnected Stream- Aquifer Systems, Groundwater, 45(5):579-589.

852 Yu, B., Sombatpanit, S., Rose, C. W., Ciesiolka, C. A. A., \& Coughlan, K. J. (2000). 853 Characteristics and Modeling of Runoff Hydrographs for Different Tillage Treatments, Soil 854 Science Society of America Journal, 64, 1763-1770, doi: 10.2136/sssaj2000.6451763x. 
855 


\section{Figure captions}

857 Figure 1: Lateral outflow (a) and inflow (b) during floods; two examples of combined cases are also given (c); dark and light blue colours are used to differentiate water levels before and during the flood, respectively, in surface water and groundwater (dashed lines).

Figure 2: Diffusive wave model on a reach without lateral flow (a), and with uniformly distributed lateral flows along a channel reach according to two cases: gains (b) and losses (c). The black curve $Q_{I f}$ depicts the input hydrograph, and the blue curve $Q_{o f}$ the output one at the end of the reach. The direct approach of the DWE is used to route $Q_{I f}$ at the end of the reach without lateral exchanges $Q_{I f r}$ (dashed grey curve). In the case of lateral flows, the inverse approach is used to simulate lateral flow $Q_{A f}$ (dotted red curve), which is positive for lateral inflow into the reach (b), or negative for lateral outflow from the reach (c). Terms $E, E_{D}$ and $E_{A}$ are attenuation and/or amplification terms explained in the text (Section 2.3).

Figure 3: Sensitivity analysis of the inverse problem of the DWE to simulate lateral flow $\left(Q_{A f}\right.$ - red dotted line) for various parameterization sets of $C$ (in $\mathrm{m} / \mathrm{s}$ ) and $D\left(\right.$ in $\left.\mathrm{m}^{2} / \mathrm{s}\right)$. The analysis is based on two theoretical mono-peak flood events used as input ( $Q_{I f}$ - black curve) and 871 output ( $Q_{O f}$ - blue curve) on a 500-m-long reach and at a computed time step of 120 s. For 872 gaining and losing reaches, respectively, a) and b) show the effect of varying $C$ and fixed $D$; 873 c) and d) the effect of varying $D$ and fixed $C$; and e) and f) the effect of varying $D$ and 874 calibrating $C$ so that peakflow time of the routed input $\left(Q_{I f r}-\right.$ dashed grey line $)$ is in phase 875 with the output $\left(Q_{O f}\right.$ - blue curve) one.

876 Figure 4: a) Location of the Iton River in France (karst aquifers map from Chen et al., 2017); 877 b) Hydrogeological map of the Iton basin, and c) Scheme illustrating the main lateral surface 878 flows (light blue colour) and lateral groundwater flows (dark blue colour) along the karst 879 reach of the Iton River (adapted from Charlier et al., 2015a; David et al., 2016). 
Figure 5: Daily input $Q_{I}(t)$ (a) and output $Q_{O}(t)$ (b) time series for the 2000-2001 hydrological

881 cycle along the reach delimited by the two gauging stations at Bourth and Normanville.

882 (c) Input-output relationships for the base component $Q_{b}$ (grey squares) and flood component $Q_{f}$ (red circles) are shown for a 2-day delay, corresponding to the mean peakflow delay.

884 Figure 6: Baseflow at the Normanville gauging station vs. groundwater level at daily time 885 steps for six piezometer wells in the Iton catchment, showing a best correlation for Coulonges 886 piezometer (right bottom).

Figure 7: Effect of (a) initial soil humidity and (b) of initial karst saturation on the inputoutput peakflow relationships ( $Q x_{O} v s$. $Q x_{I}$, respectively). Soil saturation is expressed from the HU2 index (n.d.) and karst saturation from the groundwater depth ' $z$ ' below ground level (m BGL) in the Coulonge piezometer well; circle size is proportional to the initial saturation value. The discharge threshold for overbank flow is indicated for each station.

892 Figure 8: Hydrological time series and simulated lateral flow $\left(C=0.35 \mathrm{~m} / \mathrm{s}\right.$ and $\left.D=500 \mathrm{~m}^{2} / \mathrm{s}\right)$ 893 during the flood event of 06 January 2001. From top to bottom, rainfall $P$ (at input station $P_{I}$ 894 and for lateral catchment $P_{A}$ ), soil humidity index HU2, groundwater depth in the Coulonges 895 piezometer well, discharge for the flood component, and total discharge.

896 Figure 9: Boxplot of the $C$ parameter calibrated for various diffusivity $D$ values (n=33 flood 897 events)

898 Figure 10: Outflow intensity $\left(Q n_{A f}\right) v s$. input peakflow $\left(Q x_{I f}\right)$ of the flood components, for 899 different diffusivity values.

900 Figure 11: Peakflow attenuation generated by diffusion $E_{D} v s$. peakflow amplification or 901 attenuation generated by lateral exchanges $E_{A}$. Positive $E_{A}$ values indicate amplification due to 902 lateral inflow, but compensated by a highest attenuation due to diffusion $E_{D}$ when circles are 903 below the $E_{D}=-E_{A}$ line. 


\begin{tabular}{|c|c|c|}
\hline Symbols & $\begin{array}{l}\text { Dimensi } \\
\text { on }\end{array}$ & Definitions \\
\hline$*$ & - & convolution operator \\
\hline$C$ & {$\left[\right.$ L.T $\left.^{-1}\right]$} & flood wave celerity \\
\hline$D$ & {$\left[\mathrm{~L}^{2} \cdot \mathrm{T}^{-1}\right]$} & flood wave diffusivity \\
\hline E & {$\left[\mathrm{L}^{3} \cdot \mathrm{T}^{-1}\right]$} & Difference of peakflows $Q x_{I f^{-}} Q x_{O f}$ \\
\hline$E_{A}, E_{D}$ & {$\left[\mathrm{~L}^{3} \cdot \mathrm{T}^{-1}\right]$} & $\begin{array}{l}\text { Difference of peakflows linked to the lateral flows, and to the } \\
\text { hydraulic properties of the channel, respectively }\end{array}$ \\
\hline HU2 & - & Soil humidity index \\
\hline I & - & Input station \\
\hline$K$ & - & Hayami kernel function \\
\hline$l$ & {$[\mathrm{~L}]$} & length of the channel \\
\hline$O$ & - & Output station \\
\hline$P$ & {$[\mathrm{~L}]$} & total rainfall \\
\hline$p$ & {$[\mathrm{~T}]$} & time memory of the system \\
\hline$q$ & {$\left[\mathrm{~L}^{2} \cdot \mathrm{T}^{-1}\right]$} & lateral flow per unit length \\
\hline$Q, Q_{b}, Q_{f}$ & {$\left[\mathrm{~L}^{3} \cdot \mathrm{T}^{-1}\right]$} & discharge, base, and flood components of discharge \\
\hline & {$\left[\mathrm{L}^{3} \cdot \mathrm{T}^{-1}\right]$} & mean flow discharge for a rectangular section \\
\hline$Q_{I}, Q_{I b}, Q_{I f}$ & {$\left[\mathrm{~L}^{3} \cdot \mathrm{T}^{-1}\right]$} & $\begin{array}{l}\text { discharge, base, and flood components at the input station } I \text {, } \\
\text { respectively }\end{array}$ \\
\hline$Q_{I f r}, Q_{I r}$ & {$\left[\mathrm{~L}^{3} \cdot \mathrm{T}^{-1}\right]$} & routed $Q_{I f}$, and routed $Q_{I}$, respectively \\
\hline$Q n_{A f}$ & {$\left[\mathrm{~L}^{3} \cdot \mathrm{T}^{-1}\right]$} & maximum intensity of lateral outflow \\
\hline$Q_{o}, Q_{o b}, Q_{o f}$ & {$\left[\mathrm{~L}^{3} \cdot \mathrm{T}^{-1}\right]$} & $\begin{array}{l}\text { discharge, base, and flood components at the output station } O \text {, } \\
\text { respectively }\end{array}$ \\
\hline$Q_{A}, Q_{A b}, Q_{A f}, Q_{A f r}$ & {$\left[\mathrm{~L}^{3} \cdot \mathrm{T}^{-1}\right]$} & $\begin{array}{l}\text { discharge, base, and flood components of lateral exchanges, } \\
\text { respectively }\end{array}$ \\
\hline$Q_{A f r}$ & {$\left[\mathrm{~L}^{3} \cdot \mathrm{T}^{-1}\right]$} & routed $Q_{A f}$ \\
\hline $\begin{array}{l}Q x_{A f}, Q x_{I}, Q x_{I f}, Q x_{I f r} \\
Q x_{O}, Q x_{O f}\end{array}$ & {$\left[\mathrm{~L}^{3} \cdot \mathrm{T}^{-1}\right]$} & peakflow of $Q_{A f}, Q_{I}, Q_{I f}, Q_{I f r}, Q_{O}$, and of $Q_{O f}$, respectively \\
\hline$t$ & {$[\mathrm{~T}]$} & time \\
\hline$x$ & {$[\mathrm{~L}]$} & length along the channel \\
\hline$z$ & [L] & Groundwater depth \\
\hline$\lambda$ & {$[\mathrm{L}]$} & time \\
\hline$\phi$ & - & function related to $C$ and $Q_{A f r}$ \\
\hline$\tau$ & {$[\mathrm{T}]$} & time \\
\hline
\end{tabular}

